\title{
The Brazilian experience of flex-fuel vehicles technology: towards low carbon mobility
}

\author{
D. M. Vieira do Nascimento \\ Faculty of Business, Economics and Social Sciences, \\ University of Hamburg/KlimaCampus, Germany
}

\begin{abstract}
Emerging countries are central to the climate change policy, in which the transport system plays a key role. These countries still have the majority of their traffic infrastructure based on individual-mobility meaning that public transport and alternative means of transport are not a priority yet for many reasons. As a consequence, rising $\mathrm{CO}_{2}$ emissions remain an important constraint towards sustainability in these regions. Taking into consideration the Brazilian example, this study analyses the Brazilian experience in developing and producing flex-fuel vehicles (FFV) which are cars that can run with both gasoline and bioethanol produced from sugarcane with the so-called advanced engines. It is argued here that the FFV technology developed in Brazil is an important mitigation initiative towards low-carbon urban centres and a great example of innovation in the Brazilian automotive sector. This research uses the organizational learning literature and applies the case study method to demonstrate how the process of technology transfer occurs among companies involved with this Brazilian technology, showing case-particularities and factors that facilitate or hinder the knowledge transfer process. For example, results show that some institutional aspects in the Brazilian bioethanol industry were crucial to turn this technology - initially developed to contribute to the country's energy security - into a very successful example of mitigation in the national mobility sector. Interactions among the actors within the chain, labour mobility, effective participation of research institutions and the leader role of the automaker's suppliers all enabled the rise of learning processes which were essential to the technology transfer process.
\end{abstract}

Keywords: Brazilian flex-fuel vehicles, organizational learning, mitigation technologies, technology transfer. 


\section{Introduction}

Any initiative towards the reduction of GHG emissions should take into consideration the transportation sector. The transport sector contributes significantly to carbon emissions. To exemplify, "transport activity is responsible for $13 \%$ of all anthropogenic emissions of GHG gases and $23 \%$ of world $\mathrm{CO}_{2}$ emissions from fossil fuel combustion" (OECD [1, p. 112]).

It is interesting to notice that in many countries carbon emissions as a result of transportation systems are increasing faster than carbon emissions in all other sectors OECD [1]. This shows how relevant this sector is when it comes to debates about sustainability and environment.

According to the OECD [1] report on cities and climate change, "around half of the world's population lives in urban areas, and this share is increasing over time, projected to reach $60 \%$ by 2030 " [1, p. 17]. This trend can be well observed in emerging countries like Brazil - a country with continental dimensions but where most of the population is concentrated in urban centres. Therefore, as cities account for $60 \%$ to $80 \%$ of the global energy production and $\mathrm{CO}_{2}$ emissions OECD [1] and as the transport system has a significant share on these figures, reports show that there is a tendency that urban areas in nonOECD countries may shift from a clean and relatively $\mathrm{CO}_{2}$ neutral energy system to a more $\mathrm{CO}_{2}$ intensive energetic portfolio. In Brazil, however, one can see the opposite path occurring: even though the country has a high level of personal vehicle use as incentives are still focused towards individual mobility, proper investments in public transport and alternative means of transport are not a priority yet, and Brazilian urban areas have become denser, when it comes to the transport sector carbon emissions in Brazil remain relatively low.

It is argued in this paper that the development of flex-fuel vehicles (FFV) in the country is a key factor to this "controversial" process - the ample use of the flex-fuel vehicles by consumers are contributing to the maintenance of low carbon emissions in the country's transport system despite the significant increase in population's income and number of cars in the streets. Under a policy scenario of reducing the environmental impacts of transportation and leading to low carbon mobility, this paper argues that the FFV technology developed in Brazil is now an important mitigation initiative which is supported through learning processes among stakeholders involved.

\section{The rise of the Brazilian flex-fuel vehicles technology}

According to De Cerqueira Leite et al. [2] Brazil is responsible for about $33 \%$ of all the ethanol produced in the world (some more recent studies point to $53 \%$ of production share). Presently, "bioethanol replaces around 50\% of the gasoline that would be used in Brazil if such an option did not exist" (Goldemberg [3, p. 13]). Besides, Brazil is the second biggest consumer of ethanol in the world, behind only The USA. As the light and commercial cars are responsible for a great amount of $\mathrm{CO}_{2}$ emissions in developed and non-developed countries, there are initiatives being done in order to find a more sustainable fuel 
technology and in order to further develop advanced engines. Brazil is a leader in this sector due to its national bioethanol industry and due to its FFV technology. Consequently, Brazil's flex-fuel vehicle technology, based on bioethanol fuel, and its strong national market is a success case.

For more than 30 years the country has been implementing biofuels policies to reduce the dependence on fossil fuels and to develop an alternatively national energy plan in the mobility sector. Initiatives from the producers and from the Government together with the engagement of research institutions and thinktanks are all linked to develop the best possible technological solutions, both industrial and agricultural, to increase yield, efficiency and sustainability in the sector, Corrêa do Lago et al. [4]. The country's experience with the industry can be considered an example of development based on one's own resources, demands and knowledge, as Brazil developed an efficient fuel technology and industry, becoming the sole country to implant a large-scale alternative fuel to petroleum, Zanin et al. [5].

To provide a historical overview, in 1931 the Government decided that "all the gasoline used in the country (mostly imported) should contain 5\% of ethanol from sugarcane" (Goldemberg [3, p. 13]). In 1975 The Brazilian National Alcohol Program, Pro-Alcohol Program, was implemented, contributing significantly to the impressive increase in ethanol production in Brazil. This program was created to help the country to deal with the high trade deficits resulting from the high imported crude oil prices - "Brazil was spending exceedingly large cash reserves on imported oil" (Goldemberg [3, p. 14]). Also, the program enabled Brazil to depend to a much lower degree on imported energy ("Brazil imported 34\% of its total energy consumption in 1973 in the form of crude oil. This figure dropped to $18 \%$ in 1986, after the implementation of the Pro-Alcohol Program") (Zanin et al. [5, p. 1149]). Finally, this program was implemented because international sugar prices had a significant drop. "As sugar mill owners in Brazil have always exerted a strong influence on the federal government's decisions, the alcohol program represented the ideal solution to their problems" (Zanin et al. [5, p. 1149]). The Pro-Alcohol Program was divided in two phases. In the first phase of the program, the Government took advantage of the structure and capacity of existing sugar mills to produce only hydrated alcohol (to be used in its pure form). In the second phase of the program, after 1979, hydrated ethanol began to be produced for direct use as automobile fuel, which required a complete modification of the vehicles' engine. The second oil crisis in 1979 directly influenced the drastic move towards the introduction of cars with motors designed to operate exclusively with ethanol in order to increase ethanol consumption (Goldemberg [3]). In 1985, the scenario changed completely as petroleum prices fell and sugar prices recovered in the international market. Subsidies were reduced and ethanol production was not seen as an advantage anymore. As a consequence, the production of ethanol decreased while the consumption remained relatively the same. Hence, by 1990 there was not much ethanol available in the market anymore and a serious supply crisis occurred (Goldemberg [3]). In 2003, however, the flex-fuel vehicle 
technology was developed and introduced in Brazil and ethanol consumption rose.

Brazilian flex-fuel vehicles are cars "built to run with pure gasoline, pure ethanol (hydrated ethanol) or with any mix proportion of ethanol and gasoline, from zero to $100 \%$, as they have sensors that can detect the proportion and adjust the ignition electronically" (Goldemberg [3, p. 18]). In other words, these are vehicles that can run with $100 \%$ gasoline, $100 \%$ bioethanol, or any blending standard - in the Brazilian case, E25.

The introduction of the FFV is a very interesting example of innovation in this industry. Some important figures may give an overview of the success of this technology and of the huge importance of this industry in Brazil: in the first year, 48,000 FFV were sold, about 4\% of sales. In 2006 ethanol provided $44 \%$ of the energy used for highway transportation. In 2010, the vehicle production by fuel type in Brazil was strongly based in the bioethanol fuel: $81.8 \%$ of the new vehicles registered were produced with the FFV technology, 10.2\% with diesel, and only $8 \%$ with gasoline ANFAVEA [6]. Nowadays, the flex-fuel vehicles represent the great majority of all new cars sold in the country. Only in 2010, more than 2 million new vehicles were produced with this technology. The following table demonstrates the figures mentioned above.

Table 1: Vehicle Production by fuel type.

\begin{tabular}{|c|c|c|c|c|c|c|c|c|c|c|c|}
\hline \multirow{2}{*}{$\begin{array}{l}\text { ANO } \\
\text { YEAR }\end{array}$} & \multicolumn{4}{|c|}{ 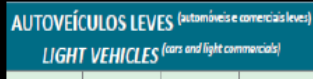 } & \multicolumn{3}{|c|}{$\begin{array}{l}\text { ÔNIBUS } \\
\text { BUSES }\end{array}$} & \multicolumn{4}{|c|}{$\begin{array}{c}\text { TOTAL DE AUTOVÉCULOS } \\
\text { VEHICLE TOTAL }\end{array}$} \\
\hline & $\begin{array}{l}\text { Gossino } \\
\text { Gososine }\end{array}$ & $\begin{array}{l}\text { Etanol } \\
\text { Ethanol }\end{array}$ & $\begin{array}{l}\text { Flexffiel } \\
\text { Flexturel }\end{array}$ & $\begin{array}{l}\text { Diesel } \\
\text { Diesel }\end{array}$ & $\begin{array}{l}\text { Gasolina } \\
\text { Gasoline }\end{array}$ & $\begin{array}{l}\text { Etenol } \\
\text { Ethanol }\end{array}$ & $\begin{array}{l}\text { Diesel } \\
\text { Diesel }\end{array}$ & $\begin{array}{l}\text { Gasolina } \\
\text { Gasoline }\end{array}$ & $\begin{array}{l}\text { Etanol } \\
\text { Ethonol }\end{array}$ & $\begin{array}{l}\text { Flexfuel } \\
\text { Flexpuel }\end{array}$ & $\begin{array}{l}\text { Diesel } \\
\text { Diesel }\end{array}$ \\
\hline 2000 & 1.471 .050 & 10.106 & & 115.726 & " & $=$ & 22.672 & .1 .971 .1660 & 10.106 & & 209.958 \\
\hline 2001 & 1.615 .476 & 19.032 & & 82014 & . & . & 23.16 & 1.615 .498 & 19.032 & & 182.586 \\
\hline 2002 & 1.576 .418 & 56.594 & & 67.134 & . & . & 22.82 & .576 .418 & 56.594 & & 158.518 \\
\hline 2003 & 1.561 .283 & 34.919 & 49.264 & 76.375 & . & . & 26.990 & 1.561 .285 & 34.919 & 49.264 & 182.323 \\
\hline 2004 & 1.682 .167 & 51012 & 332.507 & 115.45 & . & . & 28.758 & 1.682 .167 & 51.012 & 332.507 & 251.541 \\
\hline 2005 & 1.334 .189 & 51.476 & 857.899 & 133.889 & . & & 35.387 & 1.334 .189 & 51.476 & 857.899 & 287.276 \\
\hline 2006 & 977.134 & 775 & 1.391 .636 & 101.666 & . & . & 34.474 & 971.134 & 175 & 1.391 .636 & 242.784 \\
\hline 2007 & 767.368 & & 1.936 .931 & 99.539 & . & . & 38.986 & 767.368 & 3 & 1.936 .931$. & 275.806 \\
\hline 2008 & 6339.966 & & 2.243 .648 & 126921 & . & . & 44.11 & 633.960 & & 2.249 .648 & 338.362 \\
\hline 2009 & 305.756 & & 2541.153 & 97.846 & . & . & 34.539 & 385.756 & & 254.1 .153 & 86.014 \\
\hline 2010 & 660.182 & & 2.627 .111 & 121.340 & & & 45.879 & 660.182. & & 26627.111. & 338.840 \\
\hline
\end{tabular}

Source: ANFAVEA [6].

As one can see above, this technology has turned into a dominant design in the national automotive sector. Environmentally-friendly transportation policies, like the one described in this paper, require renewable energy sources, political efforts, and technology development, OECD [1]. In Brazil, this process is surrounded by learning initiatives among the involved stakeholders. That is what is described in the following section. 


\section{Learning initiatives towards low carbon mobility: the Brazilian case}

As traditional engine cars, which run only with gasoline or diesel, represent respectively only $8 \%$ and $10.2 \%$ of all new cars produced and registered (in 2010) in Brazil, while flex-fuel cars represent $81.8 \%$ of the total fleet ANFAVEA [6], the only way for automakers to enter the market is to adapt to the local dominant technology. In this sense, the study is based on the assumption that the FFV technology in Brazil has an important role in the country's mitigation strategies and energy security plans and that several situations of learning and technology transfer have since then been occurring in the sector, even if the automotive firms involved do not have a clear plan towards sustainability themselves. The answer to the question whether the auto industry is directly committed to mitigation policies in the sector or is only adapting its product to this targeted market remains still unclear for this research. However, taking into account debates about organizational learning, one can interpret that enterprises involved with this industry in the country had and still have to take part in processes of interorganizational learning in order to adapt to the local standards, highly connected with environmental issues and mitigation policies in Brazil.

Debates about climate change and its impacts on the transportation systems have shown the difficulty to mitigate in the mobility sector. In Brazil, automakers and their suppliers are key players in this sector and they are directly involved with the development of mitigation technologies. Looking into the Brazilian scenario, these firms are constantly stimulated by internal factors (such as public support, geographical location and high innovation capacities) to learn. Learning in this case acts as a provider of mitigation initiatives.

There is relevant agreement nowadays that learning is situated in a social context, is practice-based and is participative: embedded in action, not centered in an individual's head but distributed among activities, continuous interactions and relationships of people (Fenwick [7, p. 228]). Also, there is nowadays a stronger emphasis on the interorganizational level of analysis. The literature suggests that future research in organizational learning needs to move from the reasonably well-developed understanding of individual and group level learning to understanding the flows of learning between the levels (Crossan et al. [8]).

According to Bapuji and Crossan [9] recent developments in the literature suggest that much learning occurs between firms and within a network or industry. The same authors, however, argue that there is not much research made in the inter-company unit of analysis and more studies should continue to investigate learning that occurs beyond firm boundaries at the levels of interorganization, industry and population (Bapuji and Crossan [9]).

Adapting products to market needs, responding to emerging market trends, and dealing with competitive challenges are some of the reasons why companies should and do learn (Tsai [10]). Normally learning is viewed as an organizationlevel phenomenon but some learning theorists, neo-institutionalists and network theorists suggest that often learning may be produced by interactions among 
firms, rather than by isolated individual companies (Baum and Ingram [11]). According to these theorists, the context has a considerable influence in the interorganizational learning. It includes both social and material environments surrounding the firm, including other people, objects and technologies (Fenwick [7]).

Through empirical evidence, it is stated here that most of the above mentioned aspects of the learning literature are present in the Brazilian case under investigation.

The first phase of the empirical research took place in São Paulo, Brazil, in 2013. This preliminary data collection consisted of eleven expert interviews with managers and representatives of automotive industry in Brazil, sugarcane and bioethanol associations, NGO's, government and research institutions. Moreover, some of the documents provided by the interviewees were also analyzed, including the "Sugarcane-Based Bioethanol - Energy for Sustainable Future" Portfolio of the Center for Strategic Studies Management (CGEE) and of the Brazilian Development Bank (BNDES), and the "National Agro-Energy Plan 2006-2011" of the Brazilian Ministry of Agriculture. This data provided the development of an initial understanding of the sector and clarified some unclear topics.

As it was observed, bioethanol has become prominent in the Brazilian national mitigation strategy in terms of reduction of emissions and air pollution control policy. As there are still in the country more incentives towards individual transport, there is a clear tendency that in a near future all the cars produced in Brazil will be flex-fuel vehicles. Although this is now a dominant technology in the Brazilian automotive sector with great governmental and societal support, the very beginning of this sector was very obscure. Different from one could expect, it was not a genuine public initiative aiming sustainability in the sector. Brazilian government was in a first moment against the introduction of flex-fuel cars in the market due to a possible lack of fuel supply and credibility towards society. The private sector, namely automotive suppliers, had a crucial role then in the development and insertion of this technology in the country, persuading not only the government but also other reticent actors in the industry such as the alcohol producers, who did not like the idea of consumers being able to choose between their fuel and others, and the automakers, who were concerned with the costs involved and who did not have the entire headquarters' support.

It is interesting to observe that what initially was a market oriented action turned out to be now also a very important mitigation project. These partial results corroborate the research aims of investigating learning processes among enterprises involved with the development of FFV engines in Brazil, as the technology emerged as a result of interactions especially in the private sphere, showing the power and influence this sector has in the country.

The research uses the case study approach, with the use of content analysis, to analyze the industry under investigation. Although debates about climate change and concerns about $\mathrm{CO}_{2}$ emissions were not a key topic in the country by the beginning of the industry around 30 years ago, air policy control initiatives were 
already relevant in the political arena, showing some sort of early environmental awareness in Brazil. This aspect plus the country's cultural openness to biofuels (also due to a relatively uninformed population), the informal participation of the society (who used to mix alcohol to gasoline-based engines on their own) and the private pressure of the automotive industry (which has strong power in Brazil) together with the Brazilian National Alcohol Program (ProAlcool) initiative were crucial contextual drivers for the introduction of the flex engines in a large scale in Brazil.

As mentioned before, initially developed by automotive suppliers and later by car manufacturers, the FFV technology didn't receive much governmental support in the beginning due to issues related with fuel supply and public acceptance. Nevertheless, this market oriented initiative is now considered an important sustainability strategy for the mobility sector in the country, which is part of a greater mitigation policy in Brazil that focuses on bioethanol production and development.

Moreover, two important aspects which were assessed should be here emphasized: (1) the main economic, political and socio-cultural factors surrounding technology transfer in the analyzed sector in Brazil and (2) some of the industry-specific-characteristics like main goals, regulation, know-how and political interference that contribute to firms' orientation to learn.

Concerning the former, the main factors include aspects such as energy security and air policy control debates, sugarcane industry as one of the most traditional sectors in the country, insistence of local engineers and technology developers who believed in the FFV technology, availability of good supply structure and development of the concept of a "national technology" and a "national car".

The later can be exemplified by the national regulation which states that all new vehicles and engine models, domestic or imported, are required to receive emissions certification from the Brazilian Institute of Environment and Renewable Natural Resources (CETESB/IBAMA), or by the goal to consolidate ethanol as the official renewable substitute for gasoline in the country.

All these factors are important triggers for innovation in the industry and are part of the broader social environment conditions that interfere in technology transfer and learning processes. Figure 1 shows an overview of the case.

The mitigation in the Brazilian transportation sector can be seen as occurring through investments in biofuels and advanced engines. The learning initiatives of the private sector, mainly automakers and auto suppliers, and also research institutions contribute significantly to the diffusion of mitigation technologies in the country as with the example of the flex-fuel vehicle technology. This fact emphasizes the importance of applying the organizational learning literature in order to understand the phenomenon under investigation in the research. It is argued that a broader national institutional setting in Brazil can foster the interfirm learning initiatives which provide opportunities for technology transfer to occur, thus permitting the diffusion of technologies that can mitigate climate change impacts. In one hand, one can see the broader national institutional setting as formed by aspects such as government's subsidy and support, 
subsidiaries' autonomy to innovate, customers' acceptance, regulations, fuel availability, energy security debate, and sustainability and carbon emissions debate. And on the other hand, advanced innovation capabilities can also be observed as occurring among enterprises which are outside the headquarters' borders, showing the importance of local knowledge. All these aspects lead to the idea that "local" institutional and social specificities have a crucial importance in developing mitigation initiatives. This is also another reason why the research applies the learning literature. Learning is understood here as being practice-based and situated in a specific context; moreover, social practice is considered as an important source for technology acquisition. It is believed here then that these assumptions can bring interesting insights in understanding how efforts - within the private-public intersections chain - towards lower carbon emissions can be done and organized.

Figure 1: Overview of the case - How learning initiatives are leading to low carbon mobility in Brazil.

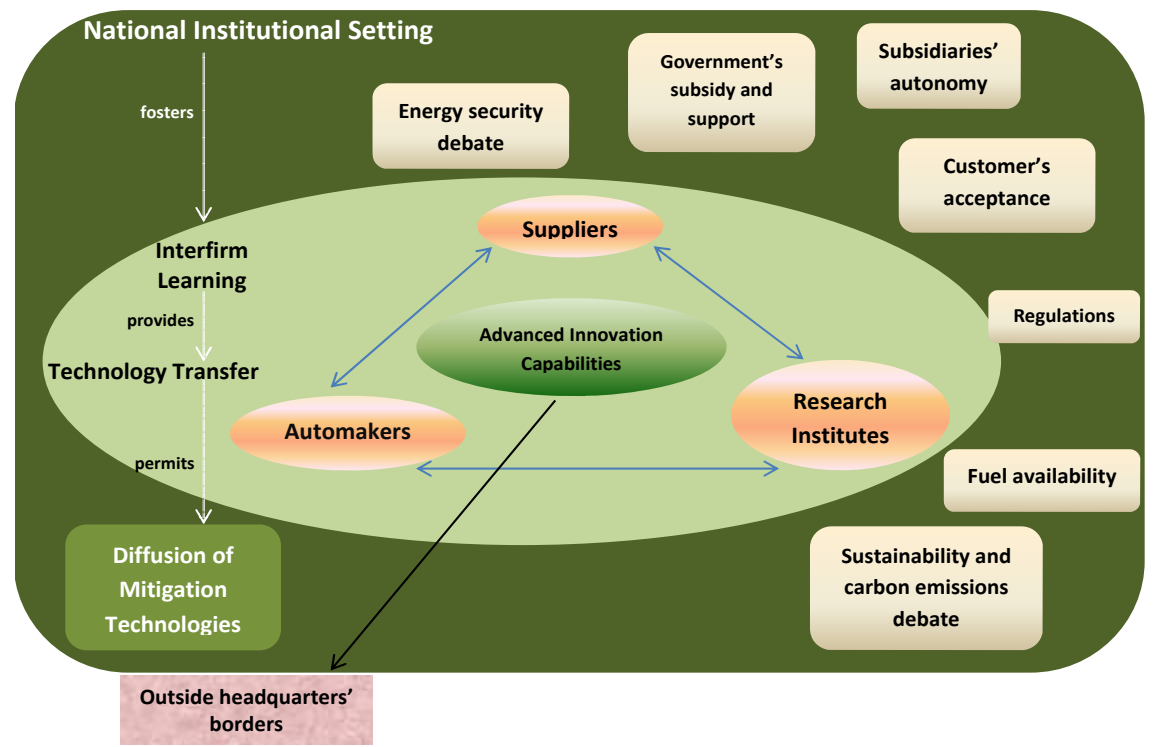

Source: the research.

\section{Conclusions}

The FFV technology developed in Brazil, point of departure of this research, was developed and put into the market by a number of different stakeholders throughout the Brazilian mobility and transportation sectors in which interorganizational learning initiatives have occurred. In order to transfer technology within the industry chain, processes of integration of external learning took place. An analysis of this scenario raised interesting insights about this growing sector and about how mitigation initiatives can be developed and 
introduced in society. Negative factors that may have hindered the process under analysis still need to be assessed though.

\section{Acknowledgements}

The researcher is grateful for the grants from the Catholic Academic Exchange Service (KAAD), from the Kompetenzzentrum Nachhaltige Universität (KNU), and from the KlimaCampus.

\section{References}

[1] OECD, Cities and climate change, OECD Publishing, 2010.

[2] De Cerqueira Leite, R. C., Verde Leal, M. R. L., Barbosa Cortez, L.A., Griffin, M. W. \& Gaya Scandiffio, M. I., Can Brazil replace 5\% of the 2025 gasoline world demand with ethanol? Energy, 34, pp. 655-661, 2009.

[3] Goldemberg, J., Sugarcane ethanol: strategies to a successful program in Brazil. In: Lee, J.W. (Ed.), Advanced Biofuels and Bioproducts, Springer, New York, pp. 13-20, 2013.

[4] Corrêa do Lago, A., Bonomi, A., Cavalett, O., Pereira da Cunha, M. \& Pinheiro Lima, M. A., Sugarcane as a carbon source: the Brazilian case. Biomass and Bioenergy, 46, pp. 5-12, 2012.

[5] Zanin, G. M., Santana, C. C., Bon, E. P. S., Giordano, R. C. L., De Moraes, F. F., Andrietta, S. R., De Carvalho Neto, C. C., Macedo, I. C., Lahr, Fo, D., Ramos, L. P. \& Fontana, J. D., Brazilian bioethanol program. Applied Biochemistry and Biotechnology, pp. 1147-1161, 2000.

[6] ANFAVEA, Anuário da indústria automobilística brasileira. São Paulo, Brasil, 2011.

[7] Fenwick, T., Understanding relations of individual collective learning in work: a review of research. Management Learning, 39(3), pp. 227-243, 2008.

[8] Crossan, M. M., Lane, H. W. \& White, R. E., An organizational learning framework: from intuition to institution. The Academy of Management Review, 24(3), pp. 522-537, 1999.

[9] Bapuji, H. \& Crossan, M., From questions to answers: reviewing organizational learning research. Management Learning, 35(4), pp. 397-417, 2004.

[10] Tsai, W., Knowledge transfer in intraorganizational networks: effects of network position and absorptive capacity on business unit innovation and performance. The Academy of Management Journal, 44(5), pp. 996-1004, 2001.

[11] Baum, J. A. C. \& Ingram, P., Survival-Enhancing learning in the manhattan hotel industry, 1898-1980. Management Science, 44(7), pp. 996-1016, 1998. 